\title{
A Chinese Cultural Interpretation of the Film The Guasha Treatment*
}

\author{
YUE Jian-ying \\ North China Electric Power University, Beijing, China
}

\begin{abstract}
The Guasha Treatment is a film about cultural conflicts experienced by a Chinese family in the USA. It vividly portrays the cultural shock experienced by Chinese immigrants to the USA and is a very good case of intercultural communication. The film highlights these Chinese cultural elements: the Guasha treatment, collectivism, Chinese concept of face, Chinese filial piety, and Chinese worship of monkey king. These cultural norms, to some extent, are hard to comprehend by Americans. This paper tends to make an analysis of the film through the perspective of Chinese culture with the aim to help foreigners understand the theme of the movie.
\end{abstract}

Keywords: The Guasha Treatment, intercultural communication, Chinese culture

\section{Introduction}

The Guasha Treatment is a Chinese movie released in 2001, which is about cultural conflicts experienced by a Chinese family in the USA. Chinese immigrant, XU Da-tong succeeded in his career after many years of struggle in America. However, an incident changed his happy life. Da-tong's father gave a simple Chinese medicine therapy called Guasha to his grandson, Dennis, which left bruise marks on the skin and the American doctor mistook it as child abuse behavior. And the Children Welfare Bureau started a lawsuit about the behavior of Dennis' father and they took action to protect Dennis. In the court, Da-tong lost his mind so that finally he lost custody of his son. The family went through hell when the child was taken away by the child protection agency. Meanwhile, the grandfather left America because he found that the living environment was really not suitable for him, as he felt that a simple, harmless treatment like Guasha, which was so common in China, was treated as child abuse in America. Furthermore, he cannot converse in English. Finally, with joint efforts, the child was able to return home and the family was reunited.

This paper interprets the film from a Chinese cultural perspective and aims to throw light on the understanding of the film. Generally speaking, the film highlights these Chinese cultural elements: the Guasha treatment, collectivism, Chinese concept of face, Chinese filial piety, and Chinese worship of monkey king.

\section{Guasha: The Medical Treatment}

As an ancient massage technique, which originated from China, with more than 2,000 years of history, Guasha is a healing technique of traditional East Asian medicine. Sometimes called "coining, spooning or scraping", Guasha is defined as instrument-assisted unidirectional press-stroking of a lubricated area of the

\footnotetext{
* Acknowledgements: The paper is supported by "The Talent Cultivation Project for Colleges and Universities" issued by Beijing (Project Number: GJ2015065).

YUE Jian-ying, lecturer, M.A., Foreign Languages Department, North China Electric Power University.
} 
body surface to intentionally create transitory therapeutic petechiae called "sha" representing extravasation of blood in the subcutis. It has been adapted by other countries throughout the East and is a common therapy in both conventional and traditional Chinese medicine today. However, it is seldom used in the West as little is known about it, and it differs greatly from Western standards.

The Chinese grandpa in the film did Guasha treatment to his grandson to help cure for his illness, however, the "sha", which is the bruise on the grandson's back was taken by the westerners as the proof of the Chinese family's maltreatment to the child.

\section{Collectivism}

Collectivism attaches importance to "we" identity over the "I" identity, group rights over individual rights and in-group-oriented needs over individual want and desires. Collectivism promotes relational interdependence, in-group harmony, and in-group collaborative spirit.

Not harming collective benefit is the precondition of what one does and what one says. When Chinese deal with the relationship of individual benefit and collective benefit, they think more of collective benefit. Sometimes, they will try their best to realize collective benefit at the expense of individual benefit. Chinese are always required to follow rules docilely and repress themselves. This kind of self-repression makes American scholars think that Chinese culture as I-less culture. Chinese culture emphasizes the full devotion to the collectivity and ignores individuality, while American culture gives a limited devotion to the collectivity. Individualism emphasizes the importance of individual identity over group identity, individual rights over group rights, and individual needs over group needs, which gives priority to individual, advocates individual benefits and individual freedom. Americans think that everyone has the freedom to do everything he wants as long as what he does will not interrupt others' benefit, and he will be responsible for what he does.

At the beginning of the film, Da-tong made a speech at his award ceremony, in which he attributes his success to his team and express his heartfelt gratitude to his boss. It is a reflection of collectivism, in which an individual values group benefits and in-group harmony. This is a typical Chinese speech made after being successful. They attribute their success to other's help and cooperation. It is what Chinese people usually do on that occasion. In China, relationship plays a critical role in people's lives. Many Chinese people get ahead with the help of their family background and friends. Therefore, they are used to extending their gratitude to other people even though their success has little to do with some of them. They seldom say that they succeed because of their own ability and hard work. When Da-tong's wife Jane gave birth to Denis at the hospital, Da-tong did not accompany her at the hospital because he had a meeting at the company. This kind of choice is understandable in China, where collectivity outweighs individuality, but is unacceptable and unforgivable in American society. And this is not only the conflict between collectivism and individualism, but also the conflict in interpersonal relationship view.

\section{The Chinese Concept of "Face"}

"Face" or "mianzi", is part of Chinese culture. Chinese care a lot about what other people think of them. Interesting as the Chinese physiological face is, the psychological face makes a still more fascinating study. It is not a face that can be washed or shaved, but a face that can be "granted" and "lost" and "fought for" and "presented as a gift". For a person to maintain face is important with Chinese social relations because face translates into power and influence and affects goodwill. A loss of "lian" would result in a loss of trust within a 
social network, while a loss of "mianzi" would likely result in a loss of authority.

Two "face"-related concepts in Chinese social relations are "guanxi" (connections; relationships) and "ganqing" (feelings). Face is central to intercultural communication or cross-cultural communication. Bert Brown explains the importance of both personal and national face in international negotiations: Among the most troublesome kinds of problems that arise in negotiation are the intangible issues related to loss of face. In some instances, protecting against loss of face becomes so central an issue that it swamps the importance of the tangible issues at stake and generates intense conflicts that can impede progress toward agreement and increase substantially the costs of conflict resolution (1977, p. 275). In terms of Edward T. Hall's dichotomy between high context cultures focused upon in-groups and low context cultures focused upon individuals, face-saving is generally viewed as more important in high context cultures such as China or Japan than in low-context ones such as the United States or Germany (Cohen, 1977).

Da-tong beat his son Dennis at the award ceremony because Dennis fought with a child, whose father is Da-tong's boss. Da-tong asked Dennis to apologize, but Dennis refused. Da-tong lost his temper and hit Dennis on the head. When Da-tong and his boss talked about it, Da-tong said he hit Dennis to show respect for his boss and to give him face. However, his boss thinks the logic is farfetched and ridiculous.

\section{Filial Piety}

In Confucian philosophy, filial piety (Chinese: 孝, xiào) is a virtue of respect for one's parents, elders, and ancestors. The term can also be applied to general obedience, and is used in religious titles in Christian Churches, like "filial priest" or "filial vicar" for a cleric whose church is subordinate to a larger parish. Filial piety is central to Confucian role ethics. In more general terms, filial piety means to be good to one's parents; to take care of one's parents; to engage in good conduct not just towards parents but also outside the home so as to bring a good name to one's parents and ancestors; to perform the duties of one's job well so as to obtain the material means to support parents as well as carry out sacrifices to the ancestors; not be rebellious; show love, respect, and support; display courtesy; ensure male heirs, uphold fraternity among brothers; wisely advise one's parents, including dissuading them from moral unrighteousness; display sorrow for their sickness and death; and carry out sacrifices after their death.

In the film, Da-tong played the role of dutiful son. It was his father who did the Guasha treatment to Dennis. Whereas, to protect his father from the judicial accusation, Da-tong lied to the court by saying he himself did the Guasha treatment. Whenever there are conflicts between his wife and his father, Da-tong tended to take side with his father by persuading his wife into understanding his father's improper behavior in the family.

\section{Chinese Worship of the Monkey King}

Monkey King is one of the main characters in the classical Chinese novel Journey to the West. Readers are fascinated with the power and wisdom of the Monkey King, who symbolizes a rebellious spirit against the feudal rulers. The monkey was born out of a rock, fertilized by the grace of Heaven and Earth. Being extremely intelligent, he has learned all the magic tricks and Gongfu from an immortal Taoist master. He can transform himself into 72 different images such as a tree, a bird.

Da-tong's family worship the monkey king, and they told Dennis the monkey king story, and the toy monkey is Dennis's favorite. All of the above indicates that Datong takes monkey king as examples of values and morals, while the opposing counsel thinks the Chinese monkey is obstreperous and rude. 


\section{Conclusion}

People's behavior and way of thinking are determined and regulated by their unique cultures. Thus, cultural clashes are bound to exist among people from different cultures in intercultural communication, as are shown in the movie. However, people can gracefully bridge the cultural gap through interaction, observation, and imitation, which is also presented by the pleasant ending of this movie.

This thesis has made an analysis of the film from the perspective of Chinese culture with the purpose of shedding light on the understanding of the movie, and keeping the foreigners informed of Chinese culture.

\section{References}

Brown, B. (1977). Face saving and face restoration in negotiation. In D. Druckman (Ed.), Negotiations: Social-psychological perspectives (pp. 275-300). Beverly Hills, CA: Sage.

Cohen, R. (1977). Negotiating across cultures: Communications obstacles in international diplomacy. Washington DC: U.S. Institute of Peace Press.

Hoebel, E. A., \& Frost, E. L. (1976). Culture and social anthropology. New York: McGraw-Hill.

Hofstede, G. (1980). Culture's consequences: International differences in work-related values. Beverly Hills: Sage.

LIN, Y. T. (1935). My country and my people. New York: Reynal \& Hitchcock. 